\title{
Penerapan Sensor Ultrasonic SRF05 Berbasis Mikrocontroller ATMega 8535 Untuk Sistem Pengereman Otomatis
}

\author{
Eri Riana \\ Fakultas Teknologi Informasi, Program Studi Sistem Informasi, Universitas Bina Sarana Informatika, Jakarta, Indonesia \\ Email: eri.eea@bsi.ac.id
}

\begin{abstract}
Abstrak-Teknologi transportasi dengan menggunakan energi listrik semakin berkembang. Mobil listrik semakin banyak digunakan untuk mengurangi penggunaan bahan bakar minyak. Selain itu performa mobil listrik yang semakin canggih, sistem keselamatan kendaraan juga harus semakin ditingkatkan. Eksistensi Artificial Intelegensi merupakan salah satu dari perkembangan kecanggihan teknologi di dunia yang semakin tak terhentikan dan tidak dapat dihindari. Salah satu mobil mewah yang digemari di Indonesia yaitu salah satunya adalah Tesla, yaitu sebuah mobil canggih dengan dukungan sistem artificial intelegensi menjadikan Tesla sebuah mobil listrik dengan fitur kendaraan kendali otomatis yang bisa berjalan tanpa menggunakan pengemudi dari manusia dan dapat melakukan proteksi keselamatan untuk pengemudi dengan menggunakan sistem pengereman otomatis bila terjadi kecelakaan yang tidak diduga. Dalam jurnal ini mengusulkan sebuah rancangan konsep masa depan cikal bakal pengereman otomatis untuk mobil listrik dengan menggunakan mikrokontroler ATMEGA 8535 sebagai kontrol otomatis utama dan sensor jarak ultrasonic. Signal PWM dari mikrokontroler digunakan untuk mengatur kecepatan motor DC sebagai penggerak utama dari kendaraan. Tampilan jarak antara kendaraan dan penghalang dapat dilihat pada LCD dan buzzer yang digunakan sebagai indikator jarak aman mobil. Percobaan dilakukan dengan menggunakan mobil remote control dengan daerah yang akan dilindungi sejauh $>500 \mathrm{~cm}(5 \mathrm{~m})$, jika sensor ultrasonic SRF05 mendeteksi adanya penghalang pada jarak tersebut, maka sensor ultrasonic SRF05 akan mengirimkan signal ke microcontroller dan menyalakan alarm dalam bentuk buzzer sehingga sensor ultrasonic SRF05 akan menghentikan propagasi signal.
\end{abstract}

Kata Kunci: Sistem Pengereman Otomatis; Mobil Listrik; Motor DC; Sensor Ultrasonic SRF05; Mikrokontroler ATMega 8535

Abstract-Transportation technology using electric energy is growing. Electric cars are increasingly being used to reduce fuel oil usage. In addition to the increasingly sophisticated performance of electric cars, the vehicle safety system must also be improved. The existence of Artificial Intelligence is one of the developments in technological sophistication in a world that is increasingly unstoppable and unavoidable. One of the most popular luxury cars in Indonesia, one of which is the Tesla, which is a sophisticated car with the support of an artificial intelligence system, making Tesla an electric car with an automatic control vehicle feature that can run without using a human driver and can provide safety protection for the driver by using automatic braking system in case of an unexpected accident. This journal proposes a future concept design for the forerunner of automatic braking for electric cars using the ATMEGA 8535 microcontroller as the main automatic control and ultrasonic distance sensor. The PWM signal from the microcontroller is used to adjust the speed of the DC motor as the main driving force of the vehicle. The display of the distance between the vehicle and the obstacle can be seen on the LCD and the buzzer is used as an indicator of the safe distance of the car. The experiment was carried out using an RC car with the area to be protected $>500 \mathrm{~cm}(5 \mathrm{~m})$, if the SRF05 ultrasonic sensor detects an obstacle at that distance, the SRF05 ultrasonic sensor will send a signal to the microcontroller and turn on an alarm in the form of a buzzer so that the SRF05 ultrasonic sensor will stop signal propagation.

Keywords: Automatic Braking System; Electric Car; DC Motor; SRF05 Ultrasonic Sensor; ATMega 8535 Microcontroller

\section{PENDAHULUAN}

Perkembangan dunia otomotif saat ini semakin meningkat dan canggih, termasuk semakin banyak diproduksinya mobil listrik. Mobil listrik yang nyaman dan memiliki kecepatan dan tenaga yang prima adalah impian dari semua pengguna. Namun seiring dengan semakin tingginya kecepatan suatu kendaraan, maka resiko akan terjadinya kecelakaan juga semakin tinggi. Enam puluh lima persen dari kecelakaan mobil yang terjadi disebabkan oleh kelalaian individu. Jika pengemudi dalam kondisi tidak prima, maka dibutuhkan suatu alat yang mampu membantu pengemudi untuk tetap berkonsentrasi dan jauh dari resiko kecelakaan di jalan raya. Jurnal ini mengusulkan perancangan cikal bakal sebuah sistem pengereman otomatis [1] untuk mobil listrik. Pengereman otomatis [2] ini dirancang dengan gagasan bahwa bila mobil melaju dan pada jarak tertentu terdapat sebuah media penghalang di depannya, maka mobil akan mengurangi kecepatannya [3] secara otomatis dan kemudian berhenti bila jarak sudah semakin dekat.

Dalam penelitian sebelumnya [4] Mardiati, R.; Ashadi, F.; Farid, G., 2016 , Rancang Bangun Prototipe Sistem Peringatan Jarak Aman Pada Kendaraan Roda Empat Berbasis Mikrokontroler ATMEGA328, Universitas Islam Negeri Sunan Gunung Djati, Bandung. Dimana penelitiannya membuat sebuah solusi yang dapat membantu mengurangi angka kecelakaan pada pengguna kendaraan khususnya kendaraan roda empat. Dengan menggunakan sensor ultrasonik berbasis mikrokontroler ATMEGA32 diharapkan menjadi sebuah sistem yang dapat membantu mengurangi angka kecelakaan khususnya pada kendaraan roda empat. Pada penelitian ini digunakan metode Action Research yaitu dengan melalui beberapa tahapan seperti data dan pengumpulan data, analisis kebutuhan, perancangan, implementasi, dan pengujian alat. Sistem ini memiliki cara kerja dengan memberikan suatu peringatan berupa bunyi dan tampilan ukuran jarak yang ditujukan untuk pengemudi kendaraan roda empat.

Dalam penelitian lain sementara itu [5] Mulyani, A., 2018, Perancangan Sensor Jarak Aman Kendaraan Bermotor Menggunakan Mikrokontroler Arduino Uno R3, Sekolah Tinggi Teknologi Garut, Garut. Penelitiannya merancang sebuah alat sensor jarak aman kendaraan bermotor menggunakan mikrokontroler Arduino sebagai sarana pendukung keselamatan saat berkendara (Safety Riding). Metode perancangan yang digunakan adalah R\&D (Research and Development) adalah metode penelitian yang digunakan untuk menghasilkan produk tertentu. Hasil dari penelitian 
ini adalah analisis dan produk berupa hardware prototype sensor jarak aman kendaraan bermotor menggunakan Arduino Uno yang diharapkan dapat dijadikan tolak ukur guna pengembangan teknologi yang lebih mutakhir khususnya untuk kenyamanan berlalu lintas.

Lain halnya penelitian yang dilakukan [6] Imanuel Yosua Lonteng, Gunawan, Isa Rosita, 2020, Rancang Bangun Simulasi Alat Pendeteksi Jarak Aman Antar Kendaraan Menggunakan Sensor Ultrasonik Berbasis Arduino, Universitas Mulia Balikpapan. Penelitiannya diharapkan kedepannya dapat membantu pengemudi untuk dapat menjaga jarak dengan kendaraan didepan, dan mengurangi resiko kecelakaan. Pada penelitian disimulasikan menggunakan mobil simulasi dihubungkan dengan sensor ultrasonik yang digunakan untuk mendeteksi dan menghitung jarak terhadap objek, lalu hasil jarak tersebut di proses oleh Arduino nano yang selanjutnya apabila kondisi pertama terpenuhi mobil simulasi akan melakukan pengereman, lalu apabila kondisi kedua terpenuhi mobil simulasi akan berhenti, mobil simulasi dapat berhenti sesuai dengan jarak yang diharapkan pada simulasi ini. Setelah diamati sensor akan semakin akurat apabila sudut objek penghalang terhadap sensor semakin tegak lurus.

Sementara itu [7] Rohmanu, A.; Widiyanto, A., 2018 , Sistem Sensor Jarak Aman Pada Mobil Berbasis Mikrokontroler Arduino Atmega328, STMIK Cikarang, Bekasi. Meneliti tentang Sistem Sensor Jarak Aman Pada Mobil Berbasis Mikrokontroler Arduino Atmega 328. Penelitian dilakukan dengan merancang alat untuk membantu pengemudi mendeteksi jarak aman dengan memanfaatkan sensor ultrasonic HC-SR04 yang dapat mengukur jarak aman di depan dan di belakang mobil. Alat dikendalikan dengan sebuah microcontroller yaitu Arduino uno yang keluarannya akan langsung ditampilkan pada LCD dengan menambah beberapa keluaran lain yaitu LED indicator (merah, kuning, hijau) dan juga sebuah buzzer yang akan berbunyi Ketika jarak kendaraan semakin mendekat dengan sekitarnya. Hasil yang didapatkan sensor ultrasonic dapat mendeteksi benda disekitarnya dengan jarak deteksi maksimal hingga 3 meter lebih.

Dalam penelitian ini, bertujuan untuk mengintegrasikan mikrokontroler ATMEGA 8535 [8] dengan sensor ultrasonic SRF05. Sensor ultrasonik merupakan sensor yang sangat popular untuk mendeteksi jarak, selain karena sensor yang cukup akurat, harganya juga cukup terjangkau sehingga orang akan lebih memilih menggunakan ultrasonik dibandingkan sensor yang lain. Dari masalah diatas dibuatlah alat pengereman otomatis ini menggunakan sensor ultrasonik. Penulis juga menggunakan sensor ultrasonic SRF05 [9] yang memilki kemampuan mendeteksi dengan range jarak yang lebih luas dari sensor ultrasonik biasa yang ada di pasaran. Mikrokontroler [10] adalah sebuah chip terintegrasi yang secara fisik berupa sebuah IC (Intergrated Circuit). Mikrokontroler [11] berisikan bagian-bagian utama dari CPU, Memory, I/O port dan timer seperti sebuah komputer standar, tetapi karena didesain hanya untuk menjalankan satu fungsi yang spesifik dalam mengatur sebuah sistem, mikrokontroler [12] ini bentuknya sangat kecil dan sederhana dan mencakup semua fungsi yang diperlukan pada sebuah chip tunggal.

Berdasarkan permasalahan tersebut maka dibuatlah suatu sistem pengereman otomatis dengan cara pengurangan dan penambahan sumber tegangan menggunakan metode pwm (pulse width modulation) serta menggunakan sensor ultrasonic SRF05 sebagai indikator putaran motor DC pada mobil listrik yang mampu memberikan pembacaan adanya benda pantul yang menghalangi laju mobil listrik sehingga laju mobil listrik akan terhenti sebelum terjadi tabrakan.

\section{METODOLOGI PENELITIAN}

\subsection{Instrument Penelitian}

Metode penelitian yang digunakan dalam penulisan jurnal ini adalah metode kualitatif. Instrument penelitian yang digunakan dalam jurnal penelitian ini yang pertama adalah instrument pengumpulan data, adapun cara untuk mendapat data sebagai bahan penelitian, maka dilakukan studi literature terhadap penelitian sebelumnya yang sejenis, adapun instrument selanjutnya adalah instrument pembuatan produk, meliputi software yang akan digunakan, serta hardware yang akan digunakan. Berikut ini adalah tabel yang akan menerangkan instrument penelitian yang digunakan dalam jurnal penelitian ini:

Tabel 1. Instrument Penelitian

\begin{tabular}{ll}
\hline \multicolumn{1}{c}{ Instrument Penelitian } & \multicolumn{1}{c}{ Bahan } \\
\hline Pengumpulan data & Studi literatur penelitian terdahulu yang sejenis \\
Pembuatan produk (Hardware) & Sensor Ultrasonic SRF05 \\
& Motor DC \\
& Motor Driver \\
& LCD,LED \\
& Buzzer \\
& Mikrocontroller ATMega 8535,PWM \\
& Breadboard \\
& Socket+2 (AA Battery) \\
& Laptop \\
\hline
\end{tabular}




\subsection{Tahapan Penelitian}

Alur penelitian adalah tahapan-tahapan yang dilakukan dalam penelitian jurnal ini, adapun alurnya digambarkan dalam bentuk sebuah flow chart agar lebih mudah dipahami:

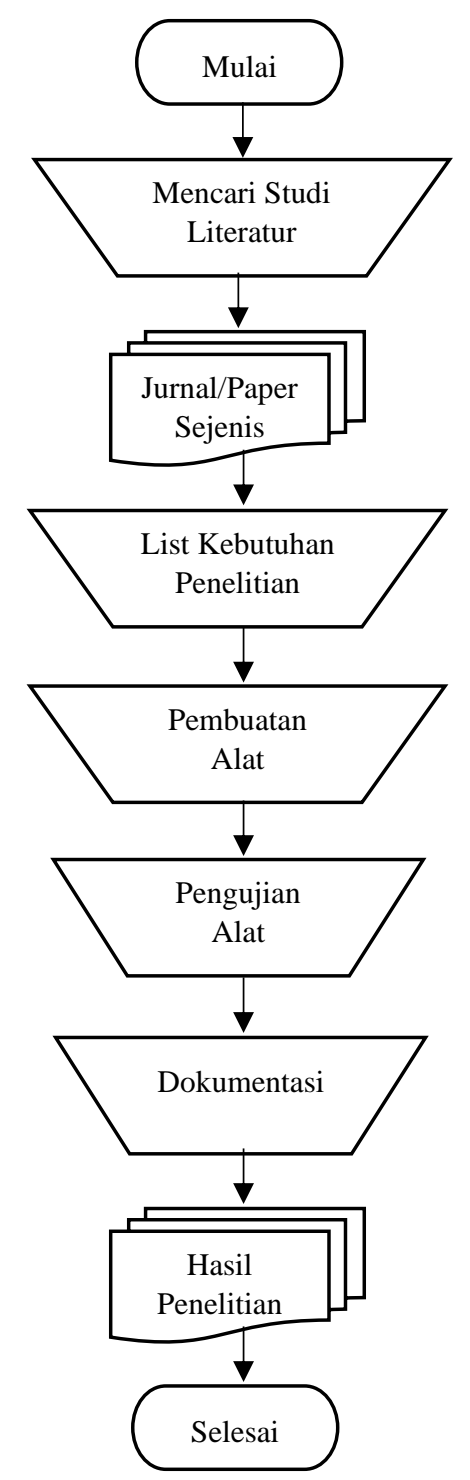

Gambar 1. Alur Penelitian

Dalam melakukan proses penelitian jurnal ini dilakukan beberapa tahapan antara lain sebagai berikut:

1) Studi Literatur

Pengumpulan data dilakukan dengan studi literatur melalui buku-buku atau artikel-artikel teknik penelitiaan

2) Jurnal/Paper Sejenis

Pengumpulan bahan penelitian melalui jurnal-jurnal/paper sejenis yang terdahulu

3) List Kebutuhan Penelitian

Mengumpulkan bahan-bahan kebutuhan penelitian baik berupa bahan hardware (perangkat keras) maupun software (perangkat lunak)

4) Pembuatan Alat

Setelah list kebutuhan penelitian dikumpulkan barulah dilakukan pembuatan rangkaian alat dengan terlebih dahulu membuat skema desain rangkaian alat seperti blok sensor ultrasonic, blok mikrocontroller, blok motor DC, blok motor driver,blok buzzer, blok LCD, blok LED

5) Pengujian Alat

Pengujian alat dilakukan dengan menempatkan prototipe pada jalur yang telah disiapkan dan memberikan halangan sebagai indicator pengereman. Jarak pengereman yang terbaca oleh sensor akan ditampilkan oleh LCD display.

6) Dokumentasi

Setelah dilakukannya pengujian alat barulah semua di dokumentasikan berupa hasil perhitungan-perhitungan dan semua skema rangkaian alat yang diteliti

7) Hasil Penelitian 
Setelah pengujian alat berhasil, kemudian dilanjutkan dengan melakukan hasil penelitian dengan melakukan analisa keakuratan jarak dari pengereman otomatis. Jarak pengereman yang terbaca oleh sensor dan ditampilkan oleh LCD display dibandingkan dengan jarak pengukuran sebenarnya

\section{HASIL DAN PEMBAHASAN}

\subsection{Prototipe Sistem}

Hasil perancangan prototipe alat yang digunakan pada sistem pengereman otomatis ini dapat dilihat pada gambar rangkaian berikut, pada perancangan prototipe ini terdapat beberapa komponen yang digunakan, diantaranya adalah :

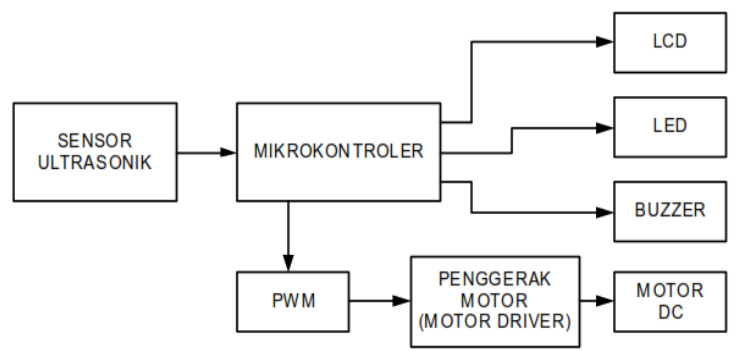

Gambar 2. Blok Diagram Perancangan

a. Mikrokontroler Atmega 8535

Mikrokontroler Atmega8535 terdiri dari rangkaian mikroprosesor dan memori yang dapat diprogram serta mempunyai saluran I/O (input/output) sebanyak 32 buah, yang terdiri dari PortA, PortB, PortC dan PortD, Analog to Digital Converter (ADC) 10 bit sebanyak 8 saluran, tiga buah Timer/Counter dengan kemampuan pembanding, CPU yang terdiri atas 32 buah register, Watchdog Timer dengan osilator internal, SRAM sebesar 512 byte, memori Flash sebesar $8 \mathrm{~Kb}$ dengan kemampuan Read While Write, unit interupsi internal dan eksternal, port antarmuka SPI, EEPROM (Electrically Ersable Programmable Read Only Memory) sebesar 512 byte yang dapat diprogram, antarmuka komparator analog, PortUSART untuk komunikasi serial dengan kecepatan maksimal 12,5 Mbps dan sistem mikroprosesor 8 bit berbasis RISC dengan kecepatan maksimal $16 \mathrm{MHz}$.

b. Sensor Ultrasonik SRF-05

Sensor ini digunakan untuk mendeteksi jarak dengan memakai gelombang ultrasonik. Sensor ini bekerja dengan tegangan suplai $5 \mathrm{~V}$ dan memberikan triger input dan echo kepada mikrokontroler seperti yang ditunjukkan pada gambar 3.

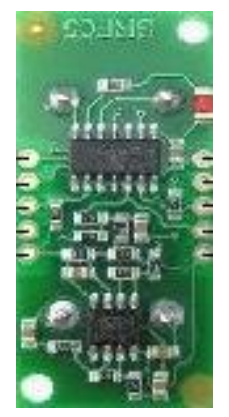

Gambar 3. Sensor Ultrasonic SRF05

c. Buzzer

Buzzer digunakan sebagai indikator bunyi dengan frekuensi kecepatan bunyinya diatur oleh mikrokontroler. Transitor Q1 pada rangkaian buzzer digunakan sebagai pemicu untuk aktif, seperti ditunjukkan pada gambar 4 di bawah ini.

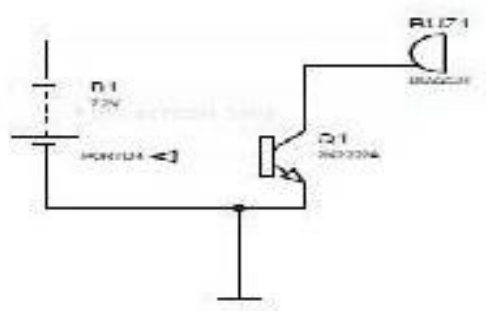

Gambar 4. Rangkaian Buzzer

Eri Riana | https://ejurnal.seminar-id.com/index.php/josh/ | Page 271 Submitted: 31/05/2021; Accepted: 01/07/2021; Published: 31/07/2021 


\section{d. Liquid Crystal Display (LCD)}

LCD digunakan untuk menampilkan nilai jarak yang terukur pada saat mobil beroperasi dan juga menampilkan hasilhasil pemrograman yang ditulis pada mikrokontroler. Rangkaian LCD ditunjukkan pada gambar 5 di bawah ini.

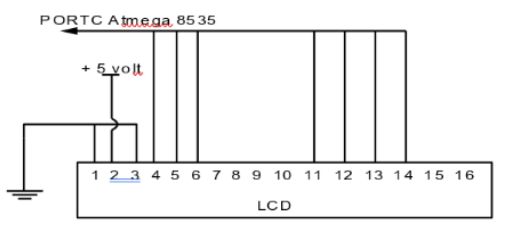

Gambar 5. Rangkaian LCD

e. Mobil Remote Control

Mobil RC adalah mobil ukuran mini yang menggunakan motor dc sebagai penggeraknya. Mobil ini dilengkapi dengan sistem gearbox dengan rasio perbandingan 10:1, berukuran panjang $49 \mathrm{~cm}$, lebar $20 \mathrm{~cm}$ dan tinggi $20 \mathrm{~cm}$. Diameter roda adalah $65 \mathrm{~mm}$. Motor dc yang digunakan mempunyai spesifikasi tegangan input dc $11,8 \mathrm{~V}$, arus $2,5 \mathrm{~A}$, tahanan jangkar Ra 0,556 dan kecepatan putar maksimum $21.000 \mathrm{rpm}$.

\subsection{Rangkaian Desain}

Berikut dibawah ini gambar keseluruhan rangkaian desain prototipe sistem pengereman otomatis yang ditunjukkan oleh diagram pada gambar 6.

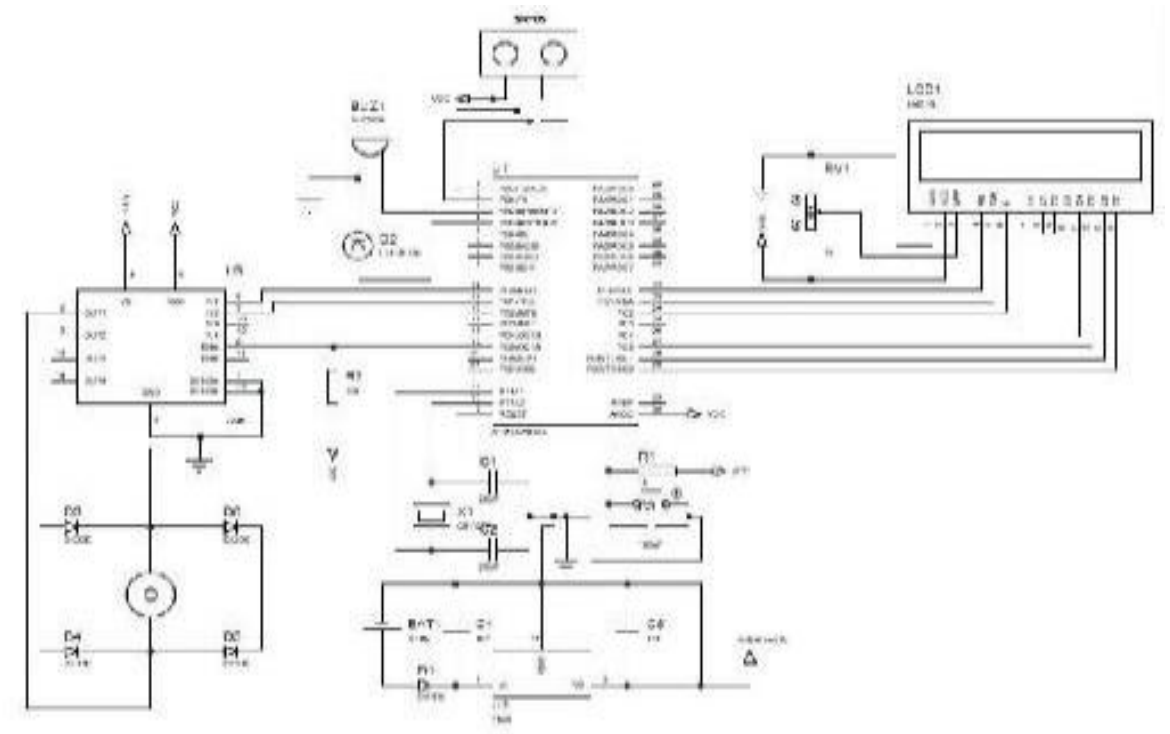

Gambar 6. Rangkaian Desain Keseluruhan

\subsection{Testing Perhitungan-Perhitungan}

a. Perhitungan Setting Jarak Sistem Pengereman Otomatis

Seting jarak dengan kecepatan untuk pengereman otomatis dibuat sebagai berikut, jarak lebih dari $5 \mathrm{~m}$ dari media penghalang, kecepatan mobil akan melaju maksimal $25 \mathrm{~km} / \mathrm{jam}$; jarak antara $2,5 \mathrm{~m}$ sampai $5 \mathrm{~m}$ dari media, kecepatan mobil $15 \mathrm{~km} / \mathrm{jam}$; jarak antara $1 \mathrm{~m}$ sampai 2,5 m, kecepatan mobil diset pada $10 \mathrm{~km} / \mathrm{jam}$; jarak kurang dari $1 \mathrm{~m}$ mobil diharapkan berhenti sempurna; jika pada jarak $50 \mathrm{~cm}$ mobil masih melaju karena gaya kinetik, maka mobil akan berputar balik dengan kecepatan $5 \mathrm{~km} / \mathrm{jam}$.

b. Perhitungan kecepatan putaran roda dan putaran motor

Perhitungan kecepatan roda dan putaran motor dc dilakukan dengan menggunakan rumus-rumus sebagai berikut:

Keliling roda $=$ Diameter roda $/ 22 / 7$

Putaran roda $=$ Kecepatan $\mathrm{x} 1.000 .000 \mathrm{rpm}$

Keliling roda $\mathrm{x} 60$

Putaran motor $=$ Putaran roda $\mathrm{x}$ rasio gearbox

Hasil perhitungan putaran roda dan putaran motor dc untuk masing-masing setting kecepatan ditunjukkan pada Tabel

2 di bawah ini. 
Journal of Information System Research (JOSH)

Volume 2, No. 4, Juli 2021

ISSN 2686-228X (media online)

Hal: $268-275$

Tabel 2. Hasil Perhitungan Putaran Roda dan Putaran Motor DC untuk berbagai Setting Kecepatan

\begin{tabular}{|c|c|c|}
\hline Kecepatan (Km/Jam) & Putaran Roda & Putaran Motor \\
\hline 25 & 2.042 & 20.420 \\
\hline 15 & $1.225,4$ & 12.254 \\
\hline 10 & 817 & 8170 \\
\hline 0 & 0 & 0 \\
\hline 5 (reverse) & 408,5 (reverse) & (reverse) \\
\hline
\end{tabular}

c. Perhitungan tegangan suplai dan PWM

Perhitungan tegangan yang diberikan pada motor dc dilakukan dengan memperhatikan nilai pada kondisi normal. Hubungan antara tegangan suplai, besar fluks medan magnet dan kecepatan motor dc adalah:

$\mathrm{V}=\mathrm{NK} \Phi+\mathrm{I}_{\mathrm{a}} \mathrm{R}_{\mathrm{a}}$

dimana $\mathrm{K}$ adalah konstanta, $\Phi$ adalah fluks medan magnet, $\mathrm{I}_{\mathrm{a}}$ adalah arus jangkar, $\mathrm{R}_{\mathrm{a}}$ adalah tahanan jangkar dan $\mathrm{N}$ adalah putaran motor.

Perhitungan nilai dan duty cycle PWM dilakukan berdasarkan setting jarak yang sudah ditentukan. Pada kondisi normal atau bernilai penuh 100\%, PWM bernilai 255 dengan tegangan keluaran 11,8V. Hubungan antara tegangan, nilai PWM dan duty cycle adalah:

$$
\frac{255}{\text { nilai PWM }}=\frac{\mathrm{V}_{\text {in }}}{\mathrm{V}_{\text {set }}}
$$

duty cycle $=\underset{\mathrm{t}_{\mathrm{off}}}{\mathrm{t}_{\text {on }}} \times 100 \%=$ nilai PWM $\mathrm{P} 100 \% \quad(6)$

Hasil perhitungan keseluruhan untuk setting jarak pengereman dan seting kecepatan untuk putaran roda, putaran motor dc, tegangan motor dc, nilai PWM dan duty cycle PWM ditunjukkan pada tabel 3 di bawah ini.

Tabel 3. Hasil Perhitungan dengan Setting Jarak dan Kecepatan

\begin{tabular}{lllllll}
\hline Jarak $(\mathrm{cm})$ & $\begin{array}{c}\text { Kecepatan } \\
(\mathrm{km} / \mathrm{jam})\end{array}$ & $\begin{array}{c}\text { Putaran } \\
\text { Roda }(\mathrm{rpm})\end{array}$ & $\begin{array}{c}\text { Putaran } \\
\text { Motor DC } \\
(\mathrm{rpm})\end{array}$ & $\begin{array}{c}\text { Tegangan } \\
\text { masukan } \\
\text { untuk motor }\end{array}$ & Nilai PWM & $\begin{array}{c}\text { Duty cycle } \\
(\%)\end{array}$ \\
\hline$>500$ & 25 & 2.042 & 20.420 & 11,8 & 255 & 100 \\
$251-$ & 15 & $1.225,4$ & 12.554 & 7,66 & 166 & 65 \\
$101-$ & 10 & 817 & 8170 & 5,55 & 120 & 47 \\
$51-$ & 0 & 0 & 0 & 0 & 0 & 0 \\
$0-50$ & 5 (reverse) & $\begin{array}{c}408,5 \\
\text { (reverse) }\end{array}$ & $\begin{array}{c}4085 \\
\text { (reverse) }\end{array}$ & 3,467 & 75 & 29 \\
\hline
\end{tabular}

Tabel 3 menggambarkan perhitungan untuk mekanisme sistem pengereman otomatis dengan cara pengurangan dan penambahan sumber tegangan menggunakan metode pwm (pulse width modulation) serta menggunakan sensor ultrasonik sebagai indikator putaran motor DC pada mobil listrik yang mampu memberikan pembacaan adanya benda pantul yang menghalangi laju mobil listrik sehingga laju mobil listrik akan terhenti sebelum terjadi tabrakan.

\subsection{Pengujian}

Sistem mekanis yang digunakan pada prototipe sistem pengereman otomatis untuk mobil listrik ini menggunakan seperangkat mobil remote control bertenaga listrik. LCD dipasang pada bagian depan mobil remote control, sensor ultrasonik SRF05 dipasang pada bumper depan, lampu LED dan buzzer dipasang pada bagian belakang mobil. Output dari rangkaian elektronik mobil remote control ini dihubungkan ke rangkaian penggerak motor yang terhubung dengan mikrokontroler. Seluruh program komputer yang ditulis pada mikrokontroler Atmega 8535 menggunakan bahasa pemrograman C. Pemrograman ditulis berdasarkan perhitungan-perhitungan yang dilakukan untuk nilai jarak yang disetting seperti yang ditunjukkan pada Tabel 4.

Tabel 4. Hasil Perhitungan dengan Setting Jarak dan Kecepatan

\begin{tabular}{lllllll}
\hline Jarak $(\mathrm{cm})$ & $\begin{array}{c}\text { Kecepatan } \\
(\mathrm{km} / \mathrm{jam})\end{array}$ & $\begin{array}{c}\text { Putaran } \\
\text { Roda }(\mathrm{rpm})\end{array}$ & $\begin{array}{c}\text { Putaran } \\
\text { Motor DC } \\
(\mathrm{rpm})\end{array}$ & $\begin{array}{c}\text { Tegangan } \\
\text { masukan } \\
\text { untuk motor }\end{array}$ & Nilai PWM & $\begin{array}{c}\text { Duty cycle } \\
(\%)\end{array}$ \\
\hline$>500$ & 25 & 2.042 & 20.420 & 11,8 & 255 & 100 \\
$251-$ & 15 & $1.225,4$ & 12.554 & 7,66 & 166 & 65 \\
$101-$ & 10 & 817 & 8170 & 5,55 & 120 & 47
\end{tabular}




\begin{tabular}{lllllll}
\hline Jarak $(\mathrm{cm})$ & $\begin{array}{c}\text { Kecepatan } \\
(\mathrm{km} / \mathrm{jam})\end{array}$ & $\begin{array}{c}\text { Putaran } \\
\text { Roda }(\mathrm{rpm})\end{array}$ & $\begin{array}{c}\text { Putaran } \\
\text { Motor DC } \\
(\mathrm{rpm})\end{array}$ & $\begin{array}{c}\text { Tegangan } \\
\text { masukan } \\
\text { untuk motor }\end{array}$ & Nilai PWM & $\begin{array}{c}\text { Duty cycle } \\
(\%)\end{array}$ \\
\hline $51-$ & 0 & 0 & 0 & 0 & 0 & 0 \\
$0-50$ & 5 (reverse) & $\begin{array}{l}408,5 \\
(\text { reverse) }\end{array}$ & $\begin{array}{l}4085 \\
\text { (reverse) }\end{array}$ & 3,467 & 75 & 29 \\
\hline
\end{tabular}

\subsubsection{Pengujian Mikrokontroler ATMega 8535}

Pengujian Mikrokontroler ATmega 8535 bertujuan untuk memastikan mikrokontroler tersebut bisa bekerja secara baik atau tidak. Keseluruhan pin input dan pin output yang ada pada mikrokontroler diperiksa dengan menggunakan sistem minimum mikrokontroler CV404. Indikator yang dilakukan dengan memberikan logika high dan logika low. Apabila diberikan logika high, maka tegangan yang diukur sekitar 4,5-5,5V, dan apabila diberikan logika low, tegangan yang diukur mendekati nol. Hasil pengujian menunjukkan tegangan yang diukur adalah 4,53V pada logika high dan $0,07 \mathrm{mV}$ pada logika low. Hal ini menunjukkan bahwa mikrokontroler bekerja dengan baik.

\subsubsection{Pengujian Kecepatan Mobil Remote Control}

Pengujian ini dilakukan untuk mengetahui seberapa besar kecepatan maksimal mobil remote control. Dari hasil pengujian ini didapatkan kecepatan maksimal sebesar $25 \mathrm{~km} / \mathrm{jam}$.

\subsubsection{Pengujian Sensor Ultrasonik SRF05}

Sensor ini mempunyai jarak jangkauan $5 \mathrm{~m}$. Jarak antara sensor dengan penghalang dapat dihitung dengan memanfaatkan pantulan gelombang ultrasonik dari penghalang. Pulsa yang diberikan sebesar $10 \mu$ s pada trigger, kemudian transceiver akan mengirimkan pulsa sebanyak 8 kali dengan frekuensi $40 \mathrm{kHz}$. Pulsa ini nantinya akan dipantulkan oleh objek yang berada didepannya. Dari data sheet sensor SRF-05, setiap $58 \mu$ s pulsa yang diterima oleh receiver berarti jarak yang diukur adalah $1 \mathrm{~cm}$. Dengan perhitungan antara kecepatan suara di udara adalah $344 \mathrm{~m} / \mathrm{s}$ dan jarak sebagai berikut : $V \mathrm{~s}=$ $344 \mathrm{~m} / \mathrm{s}=34400 \mathrm{~cm} / \mathrm{s}, \mathrm{t}=1 \mathrm{~cm} / 34400 \mathrm{~cm}=29,067 \mu \mathrm{s}$. Dalam dua arah kirim dan pantul, didapat 2t=58,1395 $\mu \mathrm{s}$. Maka, untuk jarak $1 \mathrm{~cm}$ dibutuhkan waktu $58 \mu \mathrm{s}$. Sensor diuji coba dengan mendekatkan beban ke arah sensor yang sudah terhubung dengan mikrokontroler.

Tabel 5. Perhitungan Jarak Menggunakan Sensor SRF05

\begin{tabular}{ccc}
\hline Jarak sesungguhnya $(\mathrm{cm})$ & Jarak yang terukur $(\mathrm{cm})$ & Kesalahan $(\%)$ \\
\hline 5 & 5 & 0 \\
10 & 10 & 0 \\
25 & 24 & 4 \\
50 & 48 & 4 \\
100 & 98 & 2 \\
200 & 196 & 2 \\
400 & 397 & 0,75 \\
$>500$ & $>500$ & $>0$ \\
\hline
\end{tabular}

\section{KESIMPULAN}

Berdasarkan hasil analisa pembahasan dan implementasi diperoleh kesimpulan dari penelitian jurnal ini diantaranya, pada peneltian jurnal ini dapat diketahui bagaimana membuat dan melakukan simulasi prototipe alat sistem pengereman otomatis menggunakan Sensor Ultrasonik berbasis Mikrokontroller ATMega 8535. Sensor Ultrasonik dapat mulai mendeteksi ketika suatu objek mampu memantulkan gelombang ultrasonik yang dikirim oleh sensor. Pendeteksian sensor akan semakin akurat apabila sudut kendaraan semakin tegak lurus dengan objek pantulan. Pemanfaatan sensor ultrasonik sebagai alat pemantau benda atau penghalang telah berhasil dilakukan. Hasil pengujian menunjukkan semua alat bekerja dengan baik dan efektif, dimana telah teruji pada parameter jarak.

\section{REFERENCES}

[1] Nuryanto, "Sistem Pengereman Roda Sepeda Motor Dengan Pengendali Logika Fuzzy," J. Maest., vol. 1, no. 2, pp. 330-334, 2018.

[2] D. B. Tonara and Y. M. Dinata, "Rancang Bangun Autonomous Braking System Menggunakan Sensor Infrared Berbasis Arduino," J. Semin. Nas. Sist. Inf. Infonesia, 2016.

[3] F. Musthofa and H. Winarno, "Sistem Deselerasi Kecepatan Otomatis Pada Mobil Berdasarkan Jarak Menggunakan Sensor Ultrasonik Hc-Sr04 Berbasis Arduino Mega 2560," Gema Teknol., vol. 18, no. 3, p. 110, 2015.

[4] R. Mardiati, F. Ashadi, and G. F. Sugihara, "Rancang Bangun Prototipe Sistem Peringatan Jarak Aman pada Kendaraan Roda Empat Berbasis Mikrokontroler ATMEGA32," TELKA - Telekomun. Elektron. Komputasi dan Kontrol, vol. 2, no. 1, pp. 53-61, 2016.

[5] A. Mulyani, "Perancangan Sensor Jarak Aman Kendaraan Bermotor Menggunakan Mikrokontroler Arduino Uno R3," J. Algoritm., vol. 15, no. 1, pp. 22-28, 2018. 
[6] I. R. Imanuel Yosua Lonteng, Gunawan, “Antar Kendaraan Menggunakan Sensor Ultrasonik Berbasis Arduino,” Jeecom, vol. 2, no. 2, pp. 1-5, 2020.

[7] "Jurnal Informatika SIMANTIK Vol. 3 No. 1 Maret 2018 ISSN_ - PDF Download Gratis.pdf." .

[8] J. Liliana, Welman, "PROTOTYPE PENERANGAN RUMAH OTOMATIS BERBASIS Negligence lately is made by Indonesian people are very apprehensive, almost $70 \%$ of respondents said forgot to turn off the lights . This study to minimize this by design of prototype-based home lighting ATme," J. Sains, Teknol. dan Ind., vol. 11, no. 2, pp. 273-281, 2014.

[9] S. Hani, "Sensor Ultrasonik SRF05 sebagai Memantau Kecepatan Kendaraan Bermotor," J. Teknol., vol. 3, no. 2, pp. 120-128, 2010.

[10] M. Fajar, "Perancangan Sistem Pendeteksi Jarak Aman Parkir Berbasis Mikrokontroller Arduino," Jtriste, vol. 5(1), no. 1, pp. 66-78, 2018.

[11] D. Suhartono, A. Goeritno, T. Elektro, U. Ibn, and K. Bogor, "Prototipe Sistem Berbasis Mikrokontroler untuk Pengkondisian Suhu pada Analogi Panel dengan Analogi Sistem Air Conditioning," vol. 13, no. 1, pp. 22-30, 2019.

[12] P. P. D. J. C. Henriques, I. G. A. P. R. Agung, and L. Jasa, "Rancang Bangun Sensor Jarak sebagai Alat Bantu Memarkir Mobil berbasis Mikrokontroler Arduino Uno," Maj. Ilm. Teknol. Elektro, vol. 17, no. 1, p. 72, 2018. 